\title{
Fish Fauna of River Sewa, an Important Himalayan Tributary of the River Ravi, in Kathua District of Union Territory of Jammu \& Kashmir, India
}

\author{
Gupta SC (Retd.) and SPS Dutta (Retd.)* \\ Department of Environmental Sciences, University of Jammu, India
}

*Corresponding author: SPS Dutta, Emeritus Professor, Department of Environmental Sciences, University of Jammu, India

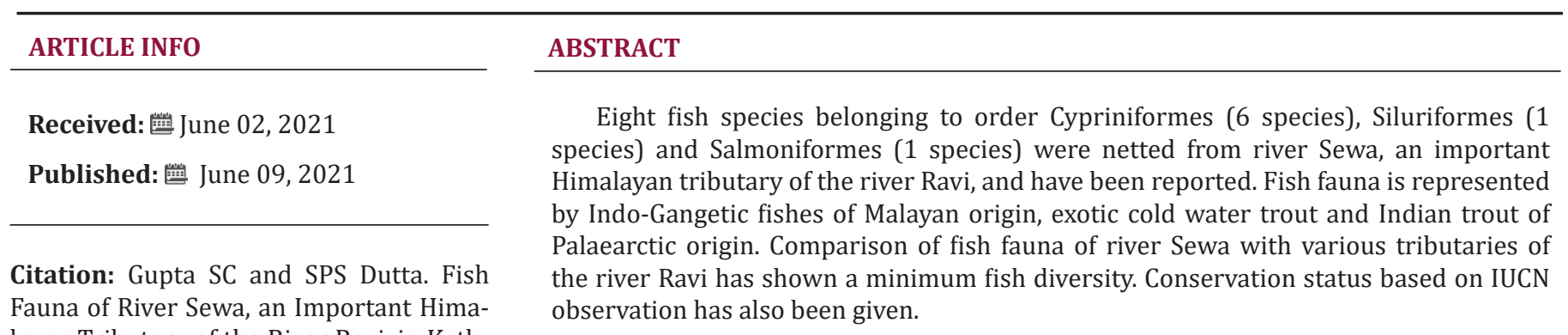
layan Tributary of the River Ravi, in Kathua District of Union Territory of Jammu \& Kashmir, India. Biomed J Sci \& Tech Res 36(3)-2021. BJSTR. MS.ID.005842.
Keywords: Fish Fauna; River Sewa; Tributary of the River Ravi; Kathua District

\section{Introduction}

Fresh water fish fauna, in the Himalayan streams, is rapidly decreasing. It is due to over exploitation, fishing during breeding season, fishing of small sized fishes, construction of reservoirs and hydroelectric projects and illegal fishing methods (poisoning, dynamiting, grenading and electric-shocking). Development of fisheries (exploitation and introduction of fishes) in any water body requires a knowledge of existing fish fauna. Our knowledge of fish fauna of the river Ravi and its tributaries has been contributed by various workers [1-13]. There is no record of fish fauna of river Sewa joining the river Ravi in Bassohli, district Kathua. This work shall be helpful for fishery department of Jammu \& Kashmir to undertake further studies and implement various developmental programs.

\section{Topography and Material and Methods}

River Sewa, an important tributary of the river Ravi, rises from the Domal structure of Kalikund in the laps of Himlayan ranges. After passing through Doda, Udhampur and Bassohli area of Kathua districts, it joins the river Ravi. The latter drains India and Pakistan.
Fishes collected by fishermen using cast net from different spots of river Sewa, in Sewa Hydroelectric project area, were studied for colour pattern and identified in laboratory [14-17].

\section{Observations and Discussion}

Fish fauna of river Sewa, is represented by Indo-Gangetic fishes of Malayan origin (Barilius vagra, Barilius bendelisis, Crossocheilus latius diplocheilus, Tor putitora and Cirrhinus reba and Glyptothorax stoliczkae), exotic cold water snout trout (Salmo trutta fario) and Indian trout (Schizothorax richardsonii) of Palaearctic origin. Eight fish species observed in Sewa river belong to order Cypriniformes (6 spp.), Siluriformes (1 sp.) and Salmoniformes (1 sp.). Fish diversity in river Sewa is lowest of all the tributaries of the river Ravi joining at different places in Indian segment. Sehgal [1] reported 16 fish species belonging to 2 order, 3 families and 11 genera from Chamba area, H.P. drained by the river Ravi. Study of fish fauna of various tributaries of the river Ravi in Kathua district started with a survey by Joshi, et al. [2] who enlisted 12 fish species belonging to 4 orders, 6 families and 11 genera from Kathua Khad and 3 fish species viz. 
Barilus vagra, Tor putitora and Channa punctatus from Ujh river. Dutta, et al. [6] noticed 27 fish species belonging to 4 orders, 8 families and 20 genera from Ujh river; 16 fish species belonging to 2 orders, 4 families and 12 genera from Tarnah nullah and total absence of fish from seasonal Kathua Khad.

Rathore, et al. [11] observed 42 fish species belonging to 5 orders, 10 families and 27 genera from river Ujh. Dutta [12] reported 64 fish species belonging to 7 orders, 17 families and 42 genera from Wajoo nullah and its tributaries. Dutta, et al. [4] surveyed fish fauna of river Basantar, an important tributary of the river Ravi, in Samba district, and enlisted 59 fish species belonging to 6 orders, 15 families and 41 genera. Sharma and Dutta. [8] documented 35 fish species belonging to 5 orders, 10 families and 25 genera, with maximum diversity and density during monsoon floods, in river Basantar. Poor fish diversity as observed in Sewa river has also been observed in a cold water torrential Neeru nullah (Schizothorax richardsonii and Glyptosernum reticulatum), Bhaderwah by Dutta, et al. [18]. This low fish diversity in river Sewa is because of torrential flow, cold water, presence of boulders and rocks and absence of soft sediments, absence of macrophytes and poor diversity of fish food organisms.

Fish conservation measures in Sewa river require:

i. Strict implementation of fishing restrictions during fish breeding period.

ii. Check on netting of small sized fishes

iii. Strict checking of illegal fishing methods

iv. Construction of pools at different places using local available materials.

v. Introduction of aquatic plants at selected places to provide shelter and food to the fish

vi. Plantation by the forest department in the catchment of the river to prevent soil erosion and to increase rain water in filtration. Plantation will also help in increasing springs and spring water discharge at various places.

The IUCN [19] Redlist showed that Tor putitora is endangered; Schizothorax richardsonii is vulnerable; Barilius vagra, Barilius bendelisis, Cirrhinus reba and Crossocheilus latius diplocheilus are least concern and Glyptothorax stoliczkae and Salmo trotta fario are in not evaluated category.

\section{References}

1. Sehgal KL (1974) Fisheries survey of Himachal Pradesh and some adjacent areas with special reference to trout, mahseer and allied species. J Bombay nat Hist Soc 70(3): 458-474.
2. Joshi CB, Sehgal KL, Sunder S (1978) Observations on the fishery resources of hill streams of Jammu province with special reference to mahseer and other commercially important species. Indian J Fish 25(12): 197-206.

3. Guglani HK (2000) Survey and systematic analysis of fish fauna of Jammu region. PhD. Thesis. University of Jammu, Jammu.

4. Dutta SPS, Bali JPS, Kour H, Sharma ID (2001) Hydrobiological studies on river Basantar, Samba, Jammu \& Kashmir. J Aquatic Biol 16(1-2): 41.

5. Dutta SPS, Kour H (2005) Fish fauna of Kathua District, Jammu region. In Proceedings National Seminar : New trends in Fishery Development in India, Punjab University, Chandigarh Feb 16-18, 233-240.

6. Dutta SPS, Gupta SC, Rathore V, Sharma A (2006) Fish fauna of some tributaries of the river Ravi; District Kathua, J\&K state, In: trends in Biodiversity and Aquaculture. Edited by Wanganeo A, Langer RK, Daya Publishing House, New Delhi: 443-452.

7. Kumar A, Dua A (2012) Fish diversity of River Ravi in Indian region. Eco Env and Cons 18(4): 861-864.

8. Sharma A, Dutta SPS (2012) Present and past status of fish fauna of river Basantar, an important tributary of the river Ravi in Samba district, Jammu (J\&K). J Applied and Natural Resources 4(1): 123-126.

9. Moza U (2014) Directorate of knowledge management in agriculture. Indian Council of Agricultural Research, New Delhi, 110012, pp. 101.

10. Dutta SPS (2015) Fish fauna of the river Ravi with a new record of Ailia puncata (Day) for Jammu and Kashmir and Punjab states and Gudusia Chapra (Ham.-Buch.) for Jammu and Kashmir state. 26 All India Congress of Zoology and International Seminar on Innovation in Animal Science for Food security, Health security and Livelihood. Organized by Baba Saheb Bhimrao Ambedkar Central University, Lucknow. $29^{\text {th }}-31^{\text {st }}$ October, 2015.

11. Rathore V, Dutta SPS (2015) Fish fauna of river Ujh, an important tributary of the river Tawi, District Kathua, Jammu. Environment Conservation J 16(1-2): 81-86.

12. Dutta SPS (2016) Fish fauna of Wajoo nullah, an important tributary of the river Ravi in Kathua district, Jammu region, Jammu and Kashmir state, India. JANS 8(2): 1087-1089.

13. Dutta SPS (2021) Fish fauna of the river Ravi and its some tributaries with a new record of Ailia punctata and Clupisoma naziri for Punjab state and Union territory of Jammu \& Kashmir, India. Aquaculture and fisheries studies 3(1): 1-5.

14. Hamilton BF (1822) An account of the fishes found in the river Ganga and its tributaries. Edinburg and London.

15. Talwar PK, Jhingran AG (1991) Inland fishes of India and adjacent countries. Oxford and IBH publishing Co. Pvt. Ltd., New Delhi.

16. Day F (1994) The fishes of India, being a natural history of the fishes known to inhabit seas and freshwaters of India, Burma and Ceylon. Fourth India Reprint, Jagmandir Book Agency, New Delhi 1(2).

17. Jayaram KC (2013) The freshwater fishes of the Indian region. Narendra Publishing House, Delhi.

18. Dutta SPS, Malhotra YR, Gupta SC and Shekhar C (1999) Aboitic limnology and some biological aspects of Schizothorax richardsonii (Gray and Hard) inhabiting Neeru nullah, Bhaderwah, Distt. Doda (J\&K). J Aqua Biol 14(1 \& 2): 39-42.

19. IUCN (2020) The IUCN Redlist of threatened species, version 2002, www.iucnredlist.org. 
ISSN: 2574-1241

DOI: 10.26717/BJSTR.2021.36.005842

SPS Dutta. Biomed J Sci \& Tech Res

(c) (P) This work is licensed under Creative BY Commons Attribution 4.0 License

Submission Link: https://biomedres.us/submit-manuscript.php

$\begin{array}{ll}\text { BIOMEDICAL } & \text { Assets of Publishing with us } \\ \text { RESEARCHES } & \text { - Global archiving of articles } \\ \text { - Immediate, unrestricted online access } & \text { - Rigorous Peer Review Process } \\ & \text { - Authors Retain Copyrights } \\ & \text { https://biomedres.us/ }\end{array}$

